\title{
Bacterial Genes Involved in Type I Secretion and Sulfation Are Required to Elicit the Rice Xa21-Mediated Innate Immune Response
}

\author{
Francisco Goes da Silva, Yuwei Shen, Christopher Dardick, Saul Burdman, Ram C. Yadav, \\ Alfredo Lopez de Leon, and Pamela C. Ronald \\ Dept. Plant Pathology, One Shields Ave., UC Davis, CA 95616, U.S.A. \\ Submitted 14 October 2003. Accepted 23 December 2003.
}

\begin{abstract}
Innate immunity to microorganisms relies on the specific sensing of pathogen-associated molecules by host recognition receptors. Whereas studies in animals have largely focused on the recognition of extracellular pathogen-associated molecules by the TLR (toll-like receptor) superfamily, few studies have been carried out in plants, and it is not understood how these molecules are secreted or modified. The rice $\mathrm{Xa} 21$ gene encodes a receptor-like kinase that provides immunity against strains of the bacterial pathogen Xanthomonas oryzae pv. oryzae carrying AvrXa21 activity. We identified four $X$. oryzae pv. oryzae genes that are required for AvrXa21 activity. $\operatorname{rax} A, \operatorname{rax} B$, and $\operatorname{rax} C$ encode proteins with similarity to a membrane fusion protein, an ATP-binding cassette transporter, and an outer membrane protein, respectively, of bacterial type I secretion systems. The fourth gene, $\operatorname{rax} S T$, encodes a sulfotransferase-like protein. Sequence analysis of three naturally occurring $X$. oryzae pv. oryzae strains no longer recognized by Xa21 revealed alterations in the $\operatorname{raxST}$ and $\operatorname{rax} A$ genes. The $\operatorname{rax} C$ gene complemented an Escherichia coli tolC mutant for secretion of a double glycine-leader peptide confirming the function of $\operatorname{raxC}$ in type $I$ secretion. These results indicate that bacterial type I secretion is necessary for $\mathrm{Xa21}$-mediated recognition and immunity and further suggest that type I secretion and modification of pathogen-associated molecules play an important role in triggering the innate immune response in rice.
\end{abstract}

Additional keywords: Oryza sativa, receptor kinases.

Components of innate immune systems in both plants and animals share many conserved features. Most notably, they sense the presence of pathogen-associated molecular patterns

The first four authors contributed equally to this work.

Corresponding author: P. C. Ronald; E-mail: pcronald@ucdavis.edu

Current address of Y. Shen; DNA LandMarks, 84 Richilieu, St. Jean Sur. Richilieu, Quebec J3B 6X3, Canada.

Current address of S. Burdman; Dept. Plant Pathology, Hebrew University of Jerusalem, Rehovot 76100, Israel.

Current address of R. C. Yadav; Department of Biotechnology and Molecular Biology, CCS Haryana Agricultural University, Hisar-125004, India.

Current address of A. L. de Leon; Novozymes Biotech, 1445 Drew Ave. Davis, CA 95616, U.S.A.
(PAMP), which represent conserved molecular structures, and avirulence (Avr) factors, which are strain-specific molecules produced by phytopathogens that are recognized by the host via cell surface or cytoplasmic receptors (Janeway and Medzhitov 1997; Slot and Knogge 2002). These receptors share common protein domains, such as leucine rich repeats (LRR) that act as ligand recognition domains and conserved signaling domains such as toll-interleukin 1 and serine threonine kinase domains (Medzhitov 2001).

Intracellular recognition of both PAMP and Avr factors is largely carried out by the cytoplasmic nucleotide-binding oligomerization domain (NOD)-protein family. The NOD family contains a large number of proteins from animals, plants, fungi, and bacteria (Inohara and Nunez 2003) and, in at least one case, recognizes a modified peptide (muramyl dipeptide). Genetic variation in three human Nod family members has been implicated in the development of disease (Inohara and Nunez 2003). Similarly, variations in plant Nod family members determine levels of resistance to bacterial, fungal, insect, and viral pathogens underscoring the essential role of the Nodmediated innate immune response in plant and animal biology.

In animals, recognition of PAMP in extracellular compartments or at the cell surface is largely carried out by members of the toll-like receptor (TLR) family that contain LRR in the extracellular domain and a TIR intracellular domain (Werling and Jungi 2003). All TLR activate a common signaling pathway to induce a core set of defense responses (Barton and Medzhitov 2003). Surprisingly, little is known about how plant hosts sense and respond to pathogen-associated molecules at the cell surface. The best-characterized examples are the Arabidopsis FLS2 receptor kinase that detects the PAMP flagellin, which composes the bacterial flagellum filament, and the rice $\mathrm{Xa} 21$ receptor kinase that mediates recognition of bacterial strains expressing AvrXa21 activity. Whereas plants lacking $\mathrm{Xa} 21$ are susceptible to the pathogen Xanthomonas oryzae pv. oryzae, Arabidopsis plants lacking FLS2 display no enhanced disease phenotype (Gomez-Gomez and Boller 2002), confounding the precise role of FLS2 in disease resistance. Despite these distinctions, both FLS2 and Xa21 carry LRR in the presumed extracellular domain, are members of large polymorphic gene families (in the case of Xa21, at least 40), and fall into a distinct phylogenetic subclass, the LRRXII class (Shiu and Bleecker 2001; C. Dardick and P. C. Ronald, unpublished data), suggesting that FLS2 and Xa21 mediate recognition of pathogen-associated molecules in a conserved manner.

There is increasing evidence that TLR, NOD, and plant receptor kinases share conserved recognition and signaling domains, that their signaling pathways are conserved, and that 
they recognize a diverse assortment of pathogen-associated molecules from plant and animal pathogens (Che et al. 2000; Gomez-Gomez and Boller 2002). Given the importance of these proteins in innate immune recognition and host defense, there is great interest in understanding the mechanism of secretion and the modification of the pathogen-associated molecules that they detect. As a result of intense research in the last 10 years, it is now well-established that animal and plant bacterial pathogens use type III secretion systems to secrete proteins into host cells in which they can affect host cell metabolism and, in some cases, be detected by intracellular Nod-like proteins (Galan and Collmer 1999). In contrast, little is known about the identity, production, and secretion of pathogen-associated molecules detected at the cell surface. For example, it is unknown if FLS2 and TLR5 recognize assembled flagellin or flagellin that has accumulated in the bacterial environment as a result of leaks or spillover during the construction of flagella (Gomez-Gomez and Boller 2002). The question of whether TLR or receptor kinases have evolved to detect molecules actively secreted by the bacteria or if modification of these molecules plays an important role in their specificity has not been addressed. Because bacterial type I systems secrete molecules from the bacterial cytoplasm to the bacterial cell surface or the extracellular environment, type I components are excellent candidates for the production or secretion of such molecules (Thanassi and Hultgren 2000).

In gram-negative bacteria, type I systems are composed of three distinct proteins that form a structure bridging the inner and outer membranes. The energy required for secretion is supplied by an inner membrane ATP-binding cassette (ABC) protein transporter (Thanassi and Hultgren 2000). In addition to the transporter, a membrane fusion protein (MFP), containing an $\mathrm{N}$ terminal membrane-spanning domain and a C-terminal periplasmic domain, spans the inner membrane and the periplasmic space, forming direct contact with the $\mathrm{ABC}$ transporter and a third component, an outer membrane protein (Thanassi and Hultgren 2000). The complex formed by multimers of these three proteins is thought to form a pore through which molecules are actively transported (Thanabalu et al. 1998).

ABC transporters are grouped into subclasses based on phylogenetic analysis. These groups not only reflect sequence similarity, but the types of molecules secreted are similar (Paulsen et al. 1997). The group of ABC transporters that secretes bacteriocins and bacteriocin-like peptides has been extensively characterized. Although these peptides show very little sequence similarity, they contain a cleavable and conserved $\mathrm{N}$ terminal double glycine (GG)-leader sequence that is required for secretion (Van Belkum et al. 1997). GG-leader peptides may aid in bacterial proliferation by offering a competitive advantage to strains that secrete them. For example, the ironregulated GG-leader peptide colicin V, found in some pathogenic Escherichia coli strains, restricts the growth of related strains of the Enterobacteriaceae family by inhibiting iron uptake and, thus, making more resources available to those strains that are immune to colicin V (Fath et al. 1994; Parker et al. 1990; Zhang et al. 1995). Type I secreted GG-leader peptides have no known role in the interaction of bacteria with their hosts.

In this study, we identified four $X$. oryzae pv. oryzae genes, $\operatorname{rax} S T, \operatorname{rax} A, \operatorname{rax} B$, and $\operatorname{rax} C$, which are required for AvrXa21 activity and $\mathrm{Xa} 21$ receptor kinase-mediated recognition and immunity. $\operatorname{rax} A, \operatorname{rax} B$, and $\operatorname{rax} C$ encode components of a bacterial type I secretion system and RaxST encodes a sulfotransferase-like protein. Our results thus demonstrate the involvement of type I secretion and modification in the production of bacterial pathogen-associated molecules that are recognized at the cell surface.

\section{RESULTS}

\section{Clone p10.78 confers AvrXa21 activity}

to $X$. oryzae pv. oryzae DY89031.

$X$. oryzae pv. oryzae DY89031 is normally virulent on rice plants containing the $\mathrm{Xa21}$ resistance gene and, therefore, lacks AvrXa21 activity. Upon inoculation of 2,000 X. oryzae
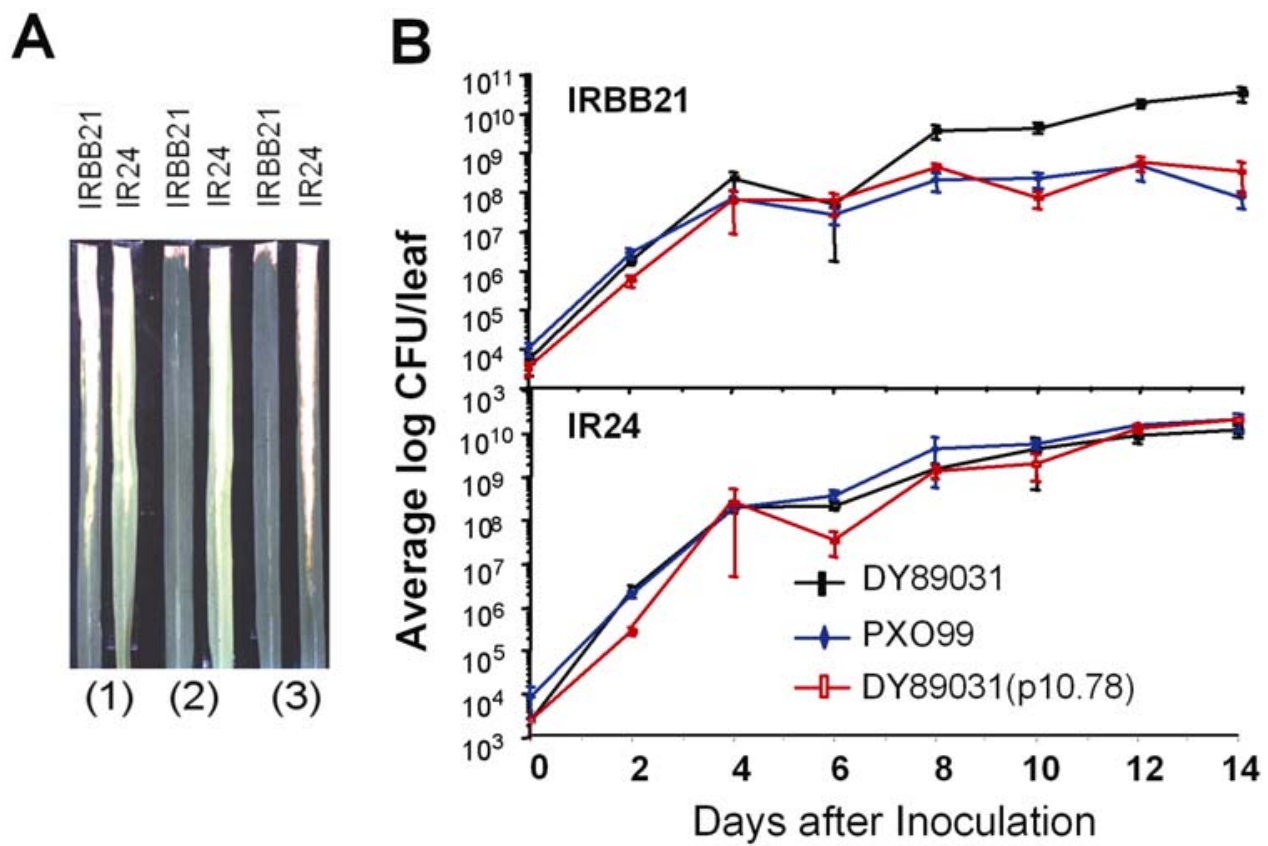

Fig 1. Phenotypes and growth of Xanthomonas oryzae pv. oryzae strains on rice. A, Lesion development on IRBB21 and IR24 rice plants inoculated with X. oryzae pv. oryzae DY89031 (1), DY89031(p10.78) (2), and PXO99 (3). B, Bacterial growth of DY89031, DY89031 (p10.78), and PXO99 inoculated on 6week-old IRBB21 and IR24 rice plants. Data points are the average of bacterial populations determined from three leaf samples. Bars represent standard deviation. 
pv. oryzae DY89031 transconjugants carrying independent PXO99 (carrying AvrXa21 activity) genomic clones, we identified one clone, named p10.78, that complemented AvrXa21 activity in DY89031 (Fig. 1A). This clone, DY89031(p10.78), grew to levels approximately 100 -fold lower than did DY89031 in Xa21 plants, comparable to the growth of the wild-type strain PXO99 (Fig. 1B). In the rice line IR24 (lacking Xa21), growth of all strains was similar, indicating that virulence of DY89031(p10.78) was not affected (Fig. 1B). Furthermore, when the p10.78 plasmid was cured from DY89031(p10.78), the strain lost AvrXa21 activity (data not shown). These results demonstrate that plasmid p10.78 contains one or more genes required for AvrXa21 activity.

\section{Three open reading frames (ORF) in p10.78 are required for AvrXa21 activity in PXO99.}

Sequencing and characterization of the PXO99 genomic insert in p10.78 revealed that it contains a 9,005-bp genomic fragment (GenBank accession numbers AF389909 and AY37358) (Fig. 2A). Nine putative complete ORF (ORF 1 to ORF 9) and one partial ORF (ORF 10) were identified, based on their similarities to other protein sequences in the database. Sequence analysis and arrangement suggests that ORF 1 to 3 (designated $\operatorname{rax} S T$, $\operatorname{rax} A$, and $\operatorname{rax} B$, or collectively $\operatorname{rax}$ $S T A B)$ are organized in a putative operon. ORF 1 shows similarity to sulfotransferases, while ORF 2 and 3 are similar to components of type I secretion systems (described below). Portions of the amino acid sequences of ORF 4, 5, and 6 shows similarity $(93,78$, and $73 \%$, respectively) to a predicted transporter of the major facilitator superfamily from $X$. axonopodis pv. citri (GenBank accession number XAC1215). This suggests that two frameshifts are present in this DNA region and, therefore, that ORF 4 to 6 do not likely encode functional proteins (Fig. 2A). ORF 7 shows 98 and 93\% similarity to conserved hypothetical proteins from $X$. axonopodis pv. citri and $X$. campestris pv. campestris (GenBank accession number XAC1216 and XCC1114, respectively). ORF 8 shows $96 \%$ similarity to a predicted dipeptidyl carboxypeptidase from $X$. axonopodis pv. citri and $41 \%$ similarity to human angiotensin converting enzyme (GenBank accession numbers XAC1217 and DCP1). The N-terminal 23 amino acids of ORF 9 show approximately 64 to $90 \%$ identity to the $\mathrm{N}$-terminal domains of prolactin-releasing peptides from cows, rats, and humans (GenBank accession numbers $\mathrm{AB} 015417, \mathrm{AB} 015418$, and AB015419, respectively), which are cleaved at the conserved GG site and to the N-terminal domain of a Bradyrhizobium japonicum ORF of unknown function (GenBank accession number 27380363). The deduced amino acid sequence of ORF 10 shows $94 \%$ similarity to the carboxy-terminus of a putative inner membrane protein from $X$. axonopodis pv. citri (GenBank accession number XAC1218), indicating that it most likely contained only the $3^{\prime}$ region of the ORF.

A p10.78 subclone, p4.8K, containing a 4.8-kb DNA insert including $\operatorname{rax} S T A B$ was the minimum fragment required for complementation of DY89031 (Fig. 2B and Table 1). PXO99

Table 1. Deletion and complementation analysis of Xanthomonas oryzae pv. oryzae inoculation on IRBB21 plants ${ }^{\mathrm{a}}$

\begin{tabular}{|c|c|c|c|c|c|c|c|c|c|}
\hline $\begin{array}{l}\text { Experiment } \\
\text { number }\end{array}$ & PXO99 & DY89031 & $\begin{array}{c}\text { DY89031 } \\
(10.78)\end{array}$ & $\begin{array}{c}\text { DY89031 } \\
\text { (p6.7K) }\end{array}$ & $\begin{array}{c}\text { DY89031 } \\
(\text { p4.8K) }\end{array}$ & $\begin{array}{c}\text { DY89031 } \\
\text { (p1.8K) }\end{array}$ & $\begin{array}{c}\text { DY89031 } \\
\text { (p6.2K) }\end{array}$ & CK89021 & $\begin{array}{c}\text { CK89031 } \\
(\operatorname{raxSTAB})\end{array}$ \\
\hline 1 & $0.7 \pm 0.3$ & $13.2 \pm 4.4$ & - & $0.6 \pm 0.2$ & - & - & - & & \\
\hline 2 & $1.1 \pm 0.2$ & $13.3 \pm 4.0$ & $1.1 \pm 0.9$ & $1.8 \pm 0.9$ & - & - & - & & \\
\hline 3 & $0.5 \pm 0$ & $13 \pm 4.1$ & $1.5 \pm 0.9$ & - & $0.7 \pm 0.3$ & - & - & & \\
\hline 4 & $0.5 \pm 0$ & $14 \pm 3.3$ & - & - & - & $13 \pm 2.0$ & $14.2 \pm 0.6$ & & \\
\hline 5 & $1.7 \pm 1.1$ & $21 \pm 3.7$ & $2 \pm 1$ & - & - & $16.4 \pm 1.5$ & $17.4 \pm 2.4$ & & \\
\hline 6 & $1.45 \pm 1.1$ & $20.5 \pm 3.9$ & $0.85 \pm 0.5$ & - & - & - & - & $20.1 \pm 3$ & $0.63 \pm 0.2$ \\
\hline 7 & $2.9 \pm 1.7$ & $18.1 \pm 3.4$ & $1 \pm 0.7$ & & & & & $16.9 \pm 1.8$ & $0.9 \pm 0.5$ \\
\hline
\end{tabular}

${ }^{a}$ Lesion lengths (in $\mathrm{cm}$, average \pm standard deviation) were measured 14 days after inoculation. Plants ( 3 to 5 per treatment) were inoculated in each experiment (with 4 to 8 leaves per plant being inoculated). IR24 plants (susceptible controls) were used in all experiments, and all strains were similarly virulent to this variety, with lesion lengths ranging between 15 and $25 \mathrm{~cm}$ in different experiments
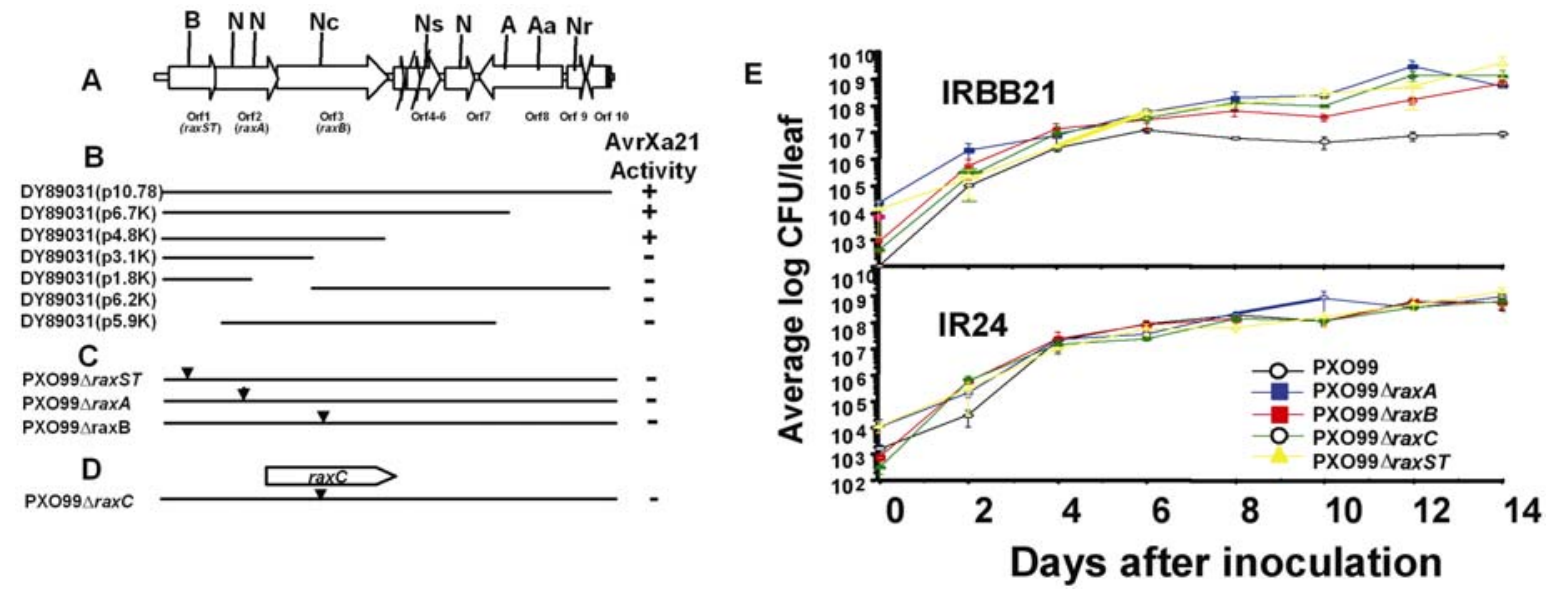

Fig. 2. The $\operatorname{rax} S T A B$ and $\operatorname{rax} C$ genomic regions, subclones, and marker-exchange mutants. A, The 10 putative open reading frames (ORF) of p10.78 with relevant restriction enzyme sites. $\mathrm{B}=B s i W \mathrm{I}, \mathrm{N}=N o t \mathrm{I}, \mathrm{Nc}=N c o \mathrm{I}, \mathrm{Ns}=N s i \mathrm{I}, \mathrm{A}=A p a \mathrm{I}, \mathrm{Aa}=A a t \mathrm{II}$, and $\mathrm{Nr}=N r u$ I. Open arrows indicate location and direction of gene transcription. Diagonal lines on ORF 4 through 6 indicate possible frameshift mutations. B, Deletion analysis of PXO99 clone p10.78 and results of inoculation of DY89031 transconjugants carrying p10.78 subclones on IRBB21(Xa21) and IR24 (xa21). C and D, Marker-exchange mutants of $\operatorname{raxST}, \operatorname{rax} A, \operatorname{rax} B$, and $\operatorname{rax} C$. Dark arrows indicate the insertion sites of the kanamycin-resistance gene. For $\mathrm{B}, \mathrm{C}$, and $\mathrm{D}$, strain names are shown on the left. "+" indicates AvrXa21 activity, and "-" indicates no AvrXa21 activity. E, Bacterial growth curves of PXO99, PXO99 $\operatorname{raxA}, \mathrm{PXO} 99 \Delta \operatorname{raxB}, \mathrm{PXO} 99 \Delta \operatorname{raxC}$, and PXO994raxST inoculated on 6-week-old IRBB21 and IR24 rice plants. Bars indicate standard deviations of three replicates. 
marker exchange mutagenesis in any one of the three ORF resulted in loss of AvrXa21 activity (Fig. 2C and Table 2). The marker exchange mutants grew to levels from 100- (for PXO994raxA and PXO994raxB) to 1,000-fold (PXO994 $\operatorname{rax} S T$ ) higher on $\mathrm{Xa21}$ plants than did the wild-type strain PXO99 (Fig. 2E). No changes in virulence were observed when the marker exchange mutants were grown on the IR24 line lacking Xa21 (Fig. 2E). All marker exchange mutants regained AvrXa21 activity after introduction of the corresponding wild-type genes (data not shown).

\section{raxSTAB encodes a sulfotransferase-like protein and components of a type I secretion system.}

Sequence analysis of raxST revealed a predicted protein with characteristics of sulfotransferases (Kakuta et al. 1998; Weinshilboum et al. 1997). RaxST contains binding motifs for the 5'-phosphosulfate and the 3'-phosphate of 3'-phosphoadenosine- $5^{\prime}$-phosphosulphate (PAPS). These two motifs are conserved in other sulfotransferases, such as Rhizobium sp. NoeE (GenBank accession number Y09415), Sinorhizobium meliloti NodH (GenBank accession number X04380), and human tyrosylprotein sulfotransferase 1 (TPST1) (GenBank accession number NM_003596) (Fig. 3).

RaxA and RaxB are similar to MFP and ABC transporters, respectively, of bacterial type I secretion systems. For example, the E. coli CvaA MFP (GenBank accession number X57524) and the E. coli $\mathrm{CvaB} \mathrm{ABC}$ transporter (GenBank accession number X57524), which are involved in colicin V secretion, show 38 and $61 \%$ similarity to $\operatorname{Rax} A$ and $\operatorname{RaxB}$, respectively. RaxA and RaxB are also 36 and $66 \%$ similar to two gene products (GenBank accession numbers NP_298506 and NP_298510, respectively) of the closely related pathogen $X y$ lella fastidiosa. Sequence and phylogenetic analysis indicated that RaxB belongs to a specific family of ABC transporters that contain, in addition to the membrane spanning and ATPase domains, an N-terminal proteolytic domain of approximately 150 amino acids with two highly conserved subdomains (Fig. $4 \mathrm{~A}$ and $\mathrm{B}$ ) characteristic of ABC transporters involved in secretion of GG-leader peptides (Michiels et al. 2001). Type I components involved in the secretion of RTX toxins, proteases, and lipases showed weaker similarity to RaxA and RaxB (data not shown). Phylogenetic analysis of the predicted RaxB with other $\mathrm{ABC}$ transporters revealed that it grouped among the GG-leader secretion clad (Fig. 4C).

\section{X. oryzae pv. oryzae strains lacking AvrXa21 activity contain genomic alterations in $\operatorname{rax} S T, \operatorname{rax} A$, or both.}

In addition to strain DY89031, a plasmid containing the PXO99 raxSTAB region complemented another strain, CK89021, for AvrXa21 activity (Table 1). Therefore, we sequenced the corresponding regions in DY89031 and CK89021 to investigate if the lack of AvrXa21 activity correlates with genomic alterations in $\operatorname{raxSTAB}$ in these strains.

DNA insertions were observed in the $\operatorname{raxST}$ and $\operatorname{raxA}$ genes from CK89021 and DY89031, respectively (Fig. 5). CK89021 has an insertion of 65 nucleotides at position 69 of raxST, leading to a frameshift and an early stop codon (Fig. 5). DY89031 has a DNA insertion of 26 nucleotides at position 24 (starting from the putative start codon) of $\operatorname{raxA}$, leading to a frameshift and an early stop codon (Fig. 5). In both cases, the insertions were caused by DNA duplication events of immediately adjacent fragments. Sequence analysis of a third AvrXa21 ${ }^{-}$strain (Philippine strain C21203) revealed the insertion of a single nucleotide in $\operatorname{rax} A$, resulting in a frameshift and early stop codon (Fig. 5). While complementation of this strain with a construct containing $\operatorname{raxSTAB}$ was not possible (strain C21203 could not be transformed by the methods outlined here), the presence of this mutation is consistent with a role for $\operatorname{raxA}$ in AvrXa21 activity in $X$. oryzae pv. oryzae strains.

Sequence comparison of raxST among PXO99, PXO86 (carrying AvrXa21 activity), and DY89031 showed two additional differences between these strains (Fig. 5). DY89031 has a lysine $(\mathrm{K})$ residue instead of an asparagine $(\mathrm{N})$ at position 71 (N71K), while both PXO99 and PXO86 contained asparagine residues. Both DY89031 and PXO86 have phenylalanine $(\mathrm{F})$ residues at position 146, while PXO99 has a leucine (L) at this position. To determine the importance of N71K, we tested whether PXO994raxST could be complemented by DY89031 raxST. Xa21 plants inoculated with PXO994raxST cells carrying DY89031 raxST in plasmid pML122 showed lesions with an average size of $8.5 \mathrm{~cm}$ (data not shown), demonstrating that this strain was not fully complemented for AvrXa21 activity. This result suggests that, in addition to the insertion in $\operatorname{rax} A$, the N71K mutation of raxST in DY89031 contributes to the lack of AvrXa21 activity in this strain. Altogether, these findings suggest that naturally occurring strains lacking AvrXa21 activity contain genomic alterations in either $\operatorname{rax} S T, \operatorname{rax} A$, or both, supporting the hypothesis that these genes are required for AvrXa21 activity.

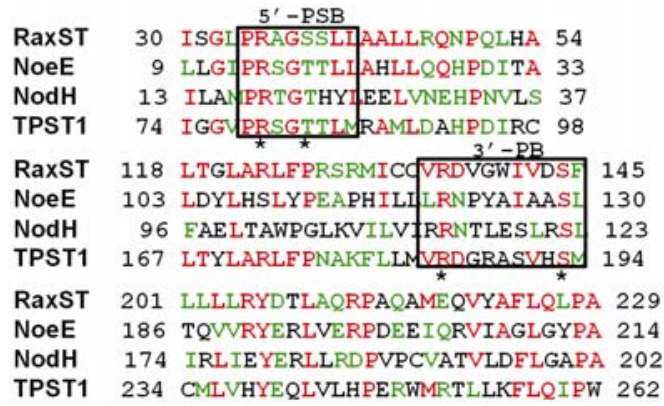

Fig. 3. Alignment of two conserved regions containing 3'-phosphoadenosine-5'-phosphosulphate binding motifs and another conserved region of unknown function of RaxST, NoeE, NodH, and TPST. 5'-PSB: 5'-phosphosulfate binding motif and 3'-PB: 3'-phosphate binding motif. Amino acids conserved in all sulfotransferases are marked with asterisks. Amino acids in red are identical, while amino acids in green are similar to RaxST.

Table 2. Inoculation of Xanthomonas oryzae pv. oryzae marker-exchange mutant strains on TP309-Xa21 and IRBB21 plants ${ }^{\mathrm{a}}$

\begin{tabular}{|c|c|c|c|c|c|}
\hline Experiment number & PXO99 & DY89031 & PXO99A raxST & PXO99 $\triangle \operatorname{raxA}$ & PX099 $\Delta$ raxB \\
\hline 1 & $1.9 \pm 0.6$ & $18.5 \pm 4.0$ & $11.8 \pm 1.0$ & $5.8 \pm 1.5$ & $4.0 \pm 2.0$ \\
\hline 2 & $0.7 \pm 0.3$ & $14.7 \pm 3.4$ & $13.0+2.7$ & - & - \\
\hline 3 & $1.9 \pm 1$ & $14.5 \pm 3.3$ & - & $7.6 \pm 1.4$ & $4.2 \pm 0.8$ \\
\hline 4 & $1.5 \pm 0.3$ & - & - & $12.9 \pm 1.2$ & $6.0+0.8$ \\
\hline
\end{tabular}

${ }^{\text {a }}$ Lesion lengths (in $\mathrm{cm}$, average \pm standard deviation) were measured 14 days after inoculation. plants ( 3 to 5 per treatment) were inoculated in each experiment (with 4 to 8 leaves per plant being inoculated). TP309-Xa21 data is shown in row 1, while IRBB21 data is shown in rows 2 to 4 . TP309 and IR24 plants (susceptible controls) were used in all experiments, and all strains caused lesion lengths ranging between 15 and $25 \mathrm{~cm}$ on these lines (data not shown). 
$X$. oryzae pv. oryzae rax $C$ shows similarity to the $E$. coli outer membrane protein $t o l C$ gene and is also required for AvrXa21 activity.

Bacterial type I secretion systems require three components for functional secretion: an ABC transporter, an MFP, and an outer membrane protein (Thanassi and Hultgren 2000). In this study, we identified $\operatorname{rax} A$ and $\operatorname{rax} B$, which encode the first two components. An $X$. oryzae pv. oryzae gene product with $51 \%$ similarity to the $E$. coli outer membrane protein TolC (which is required for colicin $\mathrm{V}$ secretion) was previously isolated in our laboratory (GenBank accession number AF389911) (Y. Shen and P. C. Ronald, unpublished data). A PXO99 markerexchange mutant strain impaired in this gene lost AvrXa21 activity (Fig. 2D and E). Therefore, the gene was named $\operatorname{raxC}$ and the marker-exchange mutant strain PXO994raxC. Growth curve analysis showed that PXO99 $\operatorname{raxC}$ grew to levels 1,000fold higher in $\mathrm{Xa21}$ plants when compared with wild-type PXO99 (Fig. 2E). Plasmids carrying the $\operatorname{raxC}$ coding sequence complemented PXO994raxC back to an AvrXa21 phenotype (data not shown). Altogether, these results demonstrate that $\operatorname{rax} C$ is also required for AvrXa21 activity.

\section{RaxC complements $E$. coli tolC mutants} for colicin $\mathrm{V}$ secretion.

To test whether $\operatorname{rax} A, \operatorname{rax} B$, and $\operatorname{rax} C$ encode proteins that function in secretion of GG-leader peptides, we tested their ability to complement E. coli $c v a A, c v a B$, and tolC mutants for colicin $\mathrm{V}$ secretion. Not surprisingly, $\operatorname{rax} A$ and $\operatorname{rax} B$ failed to complement $c v a A$ and $c v a B$, respectively (data not shown), as high efficiency transport in heterologous systems has only been observed when the leader sequences corresponding to the native GG-leader peptide are used (Van Belkum et al. 1997). In contrast, the outer membrane component is shared between many type I systems for secretion of diverse molecules and can be swapped between species (Wandersman and Delepelaire 1990). Indeed, the $E$. coli tolC mutant carrying the $\operatorname{rax} C$ gene was able to secrete colicin $\mathrm{V}$, as observed by a growth inhibition assay using the colicin $\mathrm{V}$-sensitive E. coli BL21 (Fig. 6). This result suggests that RaxC functions as an outer membrane protein for type I secretion of GG-leader peptides.

\section{DISCUSSION}

In this and in a previous study (Shen et al. 2002), we found six $X$. oryzae pv. oryzae genes that are required for Xa21 recognition. These $\operatorname{rax}$ (required for AvrXa21 activity) genes encode components of type I secretion and sulfation systems. We have also recently identified two additional genes, encoding a two-component regulatory system, that are also required for AvrXa21 activity (Burdman et al. 2004). The large number of rax genes involved in controlling AvrXa21 activity suggests that AvrXa21 plays an important role in X. oryzae pv. oryzae biology and further suggests that the rice $\mathrm{Xa} 21$ receptor kinase has evolved to recognize this molecule. Thus, Xa21-mediated recognition of AvrXa21 activity shares characteristics similar to TLR recognition of conserved molecular structures called

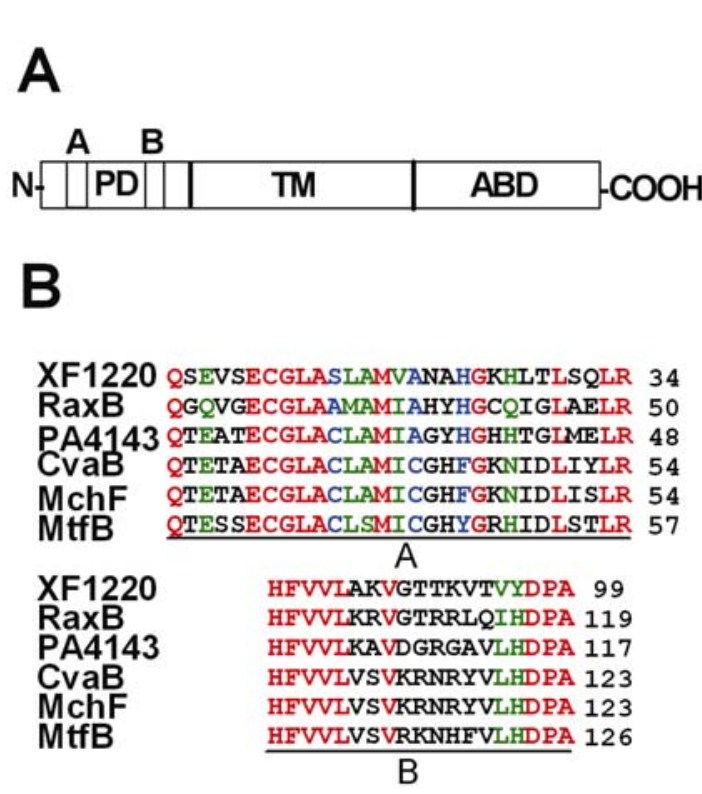

C

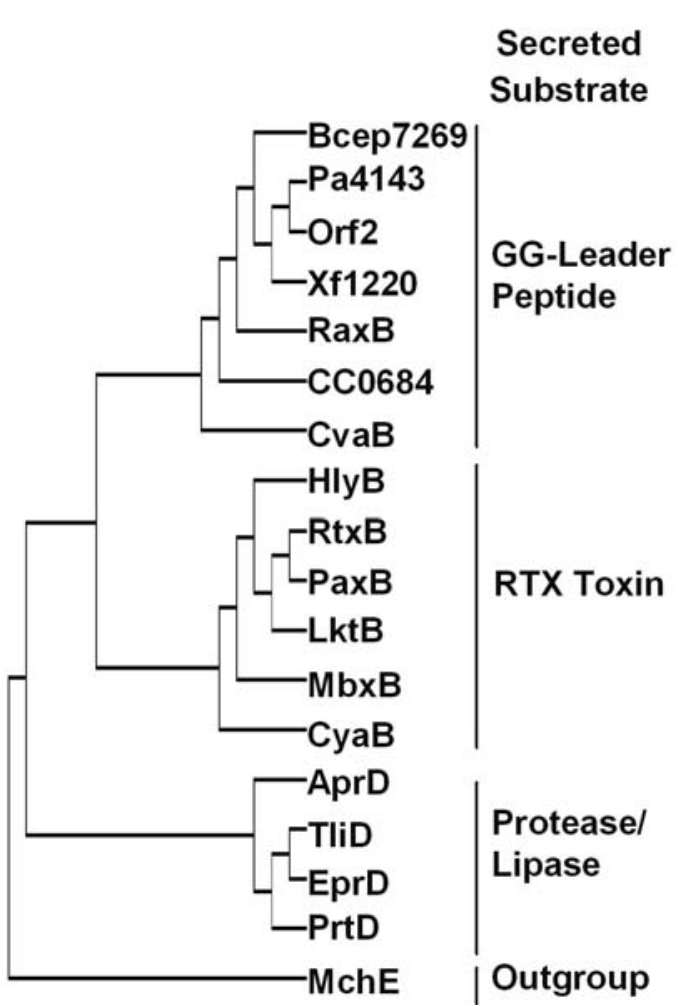

Fig. 4. Characterization of RaxB. A, Structure of the predicted $\operatorname{raxB}$ product. $\mathrm{PD}=$ proteolytic domain, $\mathrm{TM}=$ Transmembrane domains, and $\mathrm{ABD}=\mathrm{ATP}-$ binding domain. The PD was predicted according to Michiels and associates(2001), and the TM and ABD were predicted with BlastP. The proteolytic subdomains A and B are indicated by hatched boxes. B, Alignment of proteolytic subdomains A and B of RaxB, Xylella fastidiosa XF1220, Pseudomonas aeruginosa PA4143, and Escherichia coli $\mathrm{CvaB}, \mathrm{MchF}$, and MtfB. Identical amino acids are in red, and those highly and weakly conserved are in green and blue, respectively. Proteolytic subdomains A and B are underlined. Gene numbers or protein names are as in GenBank. C, Phylogenetic tree of ABC transporters. Strain designations and GenBank accession numbers are as follows: Bcep7269 Burkholderia fungorum ZP_00034377, AprD Pseudomonas aeruginosa CAA45855.1, TliD Pseudomonas fluorescens AAD09853, EprD Pseudomonas tolaasii CAA07699, CvaB E. coli P22520, HlyB E. coli M81823, MchF E. coli CAD56174, MtfB E. coli AAA88774, CyaB Bordetella pertussis CAA32412, PA4143 Pseudomonas aeruginosa A83127, XF1220 Xylella fastidiosa NP_298510, RtxB Actinobacillus pleuropneumoniae Q04473, LktB Mannheimia haemolytica P16532, CC0684 Caulobacter crescentus NP_419501, Orf2 Moraxella catarrhalis AAF61810, PrtD Erwinia amylovora CAB42874, MchE Escherichia coli Q9EXN6, PaxB Pasteurella aerogenes AAF15371, and MbxB Moraxella bovis AAP74653. 
PAMP. Interestingly, the cultivar and strain specificity of the Xa21/AvrXa21 interaction also fits the classic genetic definition of the gene-for gene model used widely to describe diverse host-parasite interactions (Flor 1971). Consequently, both PAMP (defined as a highly conserved pathogen component essential for survival) and avirulence factor can be used to describe the pathogen-associated molecule that triggers the Xa21 innate immune response. These results together with the observation that race-specific detection of flagellar variants occurs in rice (Che et al. 2000) support the idea that there is not a clear distinction between Avr factors and PAMP. Whether the precise structure recognized by $\mathrm{Xa} 21$ is highly conserved among other plant or animal bacterial pathogens and whether such a structure can be recognized by TLRs or other receptor kinases remains to be determined.

Sulfation of proteins and carbohydrates plays a key role in controlling specificity of a diverse range of extracellular recognition events (Bowman and Bertozzi 1999; Kehoe and Bertozzi 2000) The isolation of the $\operatorname{raxST}$ gene encoding a product with similarity to sulfotransferases implicates sulfation in AvrXa21 activity. Previously, Shen and associates (2002) isolated two genes, $\operatorname{rax} P$ and $\operatorname{rax} Q$, encoding an ATP sulphurylase and an adenosine-5'-phosphosulphate (APS) kinase that are required for AvrXa21 activity. These enzymes function together to produce activated forms of sulphate, APS and PAPS. RaxP and RaxQ are similar to the NodP and NodQ proteins from $S$. meliloti, which along with the sulfotransferase NodH, modify the Nod factor (Ehrhardt et al. 1995). Sulfation of the $S$. meliloti Nod factor is required for specific recognition by its host alfalfa (Roche et al. 1991). In humans, the N-terminal LRR domain on the human glycoprotein choriogonadotropin (hCG) receptor binds the C-terminal region of the alpha subunit of the hCG ligand with high affinity (Bhowmick et al. 1996). The hCG alpha subunit is sulfated at a tyrosine residue on the C-terminus, suggesting that sulfation is required for the ligand or receptor recognition (Bielinska 1987). Our data together with these studies suggest that RaxST may utilize PAPS produced by RaxP and RaxQ to transfer a sulfuryl group to a target molecule, possibly AvrXa21.

RaxA and RaxB show similarity to components of bacterial type I secretion systems involved in the secretion of GG-leader peptides (Fig. 4). We therefore hypothesize that the RaxABRaxC type I secretion system is involved in the secretion of GG-leader peptides. In support of this, $\operatorname{rax} C$ complemented an

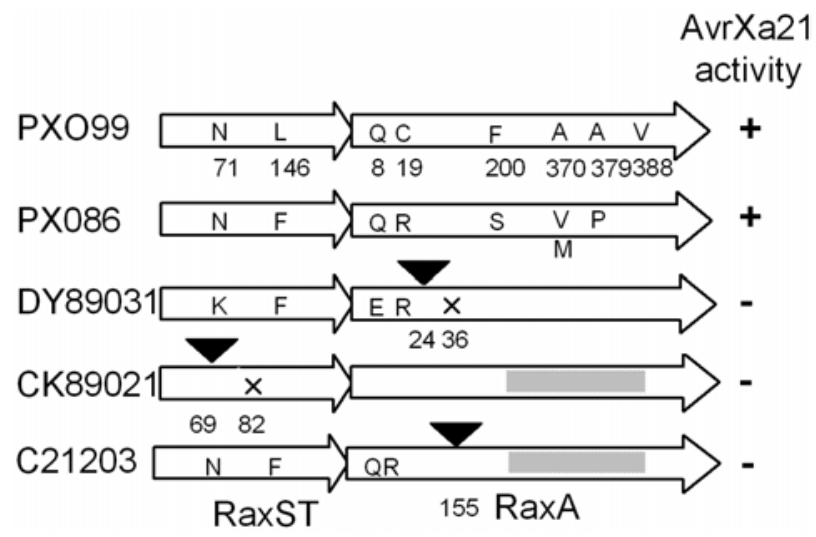

Fig. 5. Sequence comparison of RaxST and RaxA among Xanthomonas oryzae pv. oryzae strains with (+) or without (-) AvrXa21 activity. Arrows indicate direction of translation. Numbers indicate amino acid positions in the predicted proteins. Black triangles indicate DNA insertions leading to frameshifts and early stop codons are indicated by ' $\mathrm{X}$ '. Letters indicate amino acid differences among strains. Shading indicates regions not sequenced.
E. coli tolC mutant for secretion of the GG-leader peptide colicin V (Fig. 6). In some species, GG-leader peptides function as toxins (called bacteriocins) that inhibit the growth of closely related bacterial strains, as demonstrated for $E$. coli colicin V and microcins 24, B17, and H47 (DestoumieuxGarzón et al. 2002). In lactic acid bacteria, GG-leader peptides can also serve as inducing peptides that trigger two-component regulation of bacteriocin production and secretion (Dunny and Leonard 1997). Recently, we identified two genes encoding a presumed two-component regulatory system linked to raxSTAB. PXO99 mutants impaired in the histidine protein kinase or the response regulator of this two-component system show decreased AvrXa21 activity and reduced $\operatorname{raxSTAB}$ promoter activity (Burdman et al. 2004). These results suggest that the RaxAB-RaxC type I secretion system and AvrXa21 activity are regulated by a two-component system.

Mutations of the individual components of the presumed RaxAB-RaxC secretion system did not appear to completely abolish AvrXa21 activity as $\operatorname{rax} A, \operatorname{rax} B$, and $\operatorname{rax} C$ mutants did not produce lesion lengths as long as those observed for $\operatorname{rax} S T$ or wild-type virulent $X$. oryzae pv. oryzae strains (Table 2). In E. coli, HlyD and HlyB (MFP and ABC transporters, respectively, involved in the secretion of the RTX toxin hemolysin) are able to complement strains lacking CvaA and $\mathrm{CvaB}$ for colicin V secretion, although at a much lower efficiency (Fath et al. 1991). While $\operatorname{rax} A$ and $\operatorname{rax} B$ sequences were not found in the sequenced genomes of $X$. axonopodis pv. citri and $X$. campestris pv. campestris, multiple predicted type I secretion systems are present (da Silva et al. 2000). Therefore it is possible that $X$. oryzae pv. oryzae may also contain additional secretion systems that could partially complement the mutations in the $\operatorname{rax} A$ and $\operatorname{rax} B$ marker exchange mutants.

Several bacterial Avr proteins are known to affect bacterial fitness (Kearney and Staskawicz 1990; Lorang et al. 1994). While we did not observe differences in virulence in the $\operatorname{rax} S T A B$ and $\operatorname{rax} C$ marker-exchange mutants under controlled conditions, in a field study, $37 \mathrm{X}$. oryzae pv. oryzae Korean strains lacking AvrXa21 activity appeared to have reduced fitness (S. H. Choi, personal communication). In support of this field data, an additional study showed that $X$. oryzae pv. oryzae strains that lost AvrXa21 activity did not persist at the same field site into the next season, suggesting that these strains were at a competitive disadvantage (C. M. Vera Cruz, personal communication). These results leave open the possibility that AvrXa21 activity provides a fitness advantage in the field.

Based on our studies, we hypothesize that the AvrXa21 molecule may be a GG-leader peptide. Although GG-leader peptides have not been shown to interact with plant receptor kinases or TLR, it is known that other peptides can act as ligands for diverse LRR receptor kinases (-RK). For example, flagellin, systemin (a plant signaling molecule), and phytosulfokine (a sulfated peptide that acts as an intracellular signal for inducing plant cellular dedifferentiation and proliferation) are

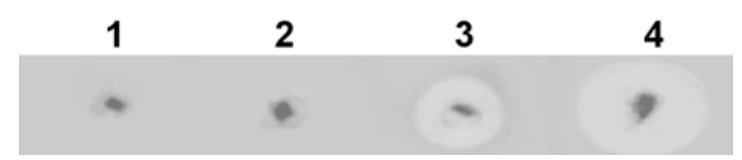

Fig. 6. Complementation of an Escherichia coli tolC mutant strain (ZK796) with $\operatorname{raxC}$. Lane $1=$ ZK796, lane $2=$ ZK796/pHK22, lane $3=$ ZK796/pHK22/pBSDY89031xC, and lane $4=$ ZK4/pHK22. Halo indicates colicin V secretion. ZK4 is a tolC wild-type strain. Plasmid pHK22 contains the $c v a A, c v a B, c v I$, and $c v a C$ genes. pBSDY89031xC contains $\operatorname{rax} C$. Colicin $\mathrm{V}$ activity was assayed by stabbing $E$. coli constructs into Luria-Bertani agar plates containing a $0.7 \%$ agarose overlay mixed with E. coli BL21 cells (sensitive to colicin V). 
all small peptides recognized by LRR-RK (Gomez-Gomez and Boller 2000; Matsubayashi et al. 2002; Scheer and Ryan 2003). With the exception of ORF 9, we were unable to identify any other putative GG-leader peptide within the $\operatorname{rax} S T A B$ genomic region. Although ORF 9 encodes a predicted peptide with a potential GG-leader sequence, a PXO99 marker exchange mutant of this ORF showed wild-type levels of AvrXa21 activity (data not shown). This result suggests that either ORF 9 is not involved in AvrXa21 activity or that there is functional redundancy in the genome. In support of the latter, the sequenced genome of the citrus pathogen, X. fastidiosa, revealed three GG-leader peptide ORF separating the $\operatorname{rax} A$ and $\operatorname{rax} B$ homologues (Michiels et al. 2001) and as many as eight additional GG-leader peptide ORF that are not closely linked (Simpson et al 2000; C. Dardick and P. C. Ronald, unpublished data). Because $X$. fastidiosa lacks type III secretion systems (Simpson et al. 2000), type I secreted GG-leader peptides may play an important role in the interaction of this pathogen with its host.

Despite the similarity of the RaxA and RaxB to the above $X$. fastidiosa predicted proteins and to other type I systems that secrete GG-leader peptides, we cannot rule out the possibility that another type of molecule is secreted. For example, RaxST remains a candidate because of its position in the putative rax$S T A B$ operon. However, preliminary data suggest that RaxST is not secreted and that it is a membrane-associated protein (data not shown). Based on these observations, we believe it is more likely that RaxST is involved in the modification of a RaxAB-RaxC secreted molecule. Many GG-leader peptides, such as E. coli microcin B17, are known to undergo a variety of posttranslational modifications that mediate their activity, and the enzymes responsible for modification are usually encoded by genes closely linked to the MFP and ABC transporter ORF (Destoumieux-Garzón et al. 2002).

Although the role of plant intracellular receptors in sensing microbial pathogen-associated molecules has been investigated intensively, the mechanism for extracellular detection of such molecules remains largely uncharacterized. The opposite situation exists in animals, in which TLR represent the most extensively studied class of extracellular PAMP-sensing systems, while detection of PAMP through intracellular receptors has only recently been demonstrated (Girandin et al. 2003). In the latter case, the human NOD2 protein recognizes a modified peptide. Despite the apparent lack of characterized plant receptors involved in extracellular recognition, over 600 receptor-like kinases have been identified in the sequenced genome of Arabidopsis thaliana, and current predictions indicate that the recently sequenced rice genome may contain as many as 1,000 (C. Dardick and P. C. Ronald, unpublished data). While many plant RK undoubtedly function in diverse pathways, many are potentially capable of recognizing pathogen-associated molecules. Due to the abundance of TLR and plant RK and their demonstrated importance in innate immune recognition and host defense, there is great interest in dissecting the cellular machinery that governs the production of the pathogen-associated molecules that they detect. Bacterial type I secretion and sulfation systems, which are found in most if not all bacterial pathogens, may play a widespread role in production of such molecules.

\section{MATERIALS AND METHODS}

\section{Strains and growth conditions.}

Bacterial strains used in this study were E. coli DH10B, X. oryzae pv. oryzae Philippine race 6 PXO99, Philippine race 2 PXO86 (both carrying AvrXa21 activity), Philippine race 10 C21203 (lacking AvrXa21 activity), and Korean race 1
DY89031 and CK89031 (both lacking AvrXa21 activity). Routine culture conditions for bacteria and concentrations of antibiotics were as described (Shen et al. 2002).

\section{PXO99 library construction and virulence assays.}

$X$. oryzae pv. oryzae genomic DNA was prepared according to Wilson (1994). A PXO99 genomic library was constructed in the plasmid pUFR027 (DeFeyter 1990) with Sau3AI-digested PXO99 DNA. DY89031 was complemented with a triparental mating procedure. Transconjugants were initially screened by inoculation on the Oryza sativa subsp. indica line IRBB21 (containing Xa21). Candidate clones for AvrXa21 activity were further inoculated on both IRBB21 and IR24 (nearly isogenic line of IRBB21 lacking Xa21) and on the Oryza sativa subsp. japonica Taipei 309 (TP309, lacking $\mathrm{Xa21}$ ) and 106-17-3-37, a TP309 transgenic line carrying the Xa21 gene (TP309-Xa21) (Song et al. 1995). Growth conditions, inoculation procedure, and in planta growth curve experiments were as described (Song et al. 1995; Wang et al. 1998).

Sequencing, similarity searches, and phylogenetic analysis.

Sequencing of the DNA insert from p10.78 was performed by the dideoxy chain termination method, using an automated sequencer (Model 400 1, LI-COR, Lincoln, NB, U.S.A.) (Sanger et al. 1977). To fill in gaps, a primer-walking strategy was used with synthesized primers (Qiagen, Valencia, CA, U.S.A.). DNA and protein sequence analyses and similarity searches were performed with Sequencher (Gene Codes Corp., Ann Arbor, MI, U.S.A.), NCBI BLAST (Altschul et al. 1997), and CLUSTAL W (Thompson et al. 1994). A phylogentic tree for $\mathrm{RaxB}$ and related proteins was generated using Treetop, based on CLUSTAL W alignments.

\section{Generation of p10.78 subclones} and marker exchange mutants.

Based on available restriction sites, subclones of p10.78 were constructed in pUFR027 in both orientations, using standard methods. Subclones were conjugated into DY89031 and tested on both IRBB21 and IR24 plants for AvrXa21 activity. Nonpolar mutations in the predicted genes were created in PXO99 by site-directed gene replacement deletion or insertion, or both, with a kanamycin-resistance gene, as described (Shen et al. 2002). These marker-exchange mutants were complemented with the wild-type gene cloned into the plasmid pML122 (Labes et al. 1990), to confirm the expected mutation. The phenotypes of the marker-exchange mutants and complemented strains were determined either by plant inoculation, growth curve experiments, or both.

\section{Cloning of $\operatorname{rax} S T A B$ homologues \\ from $X$. oryzae pv. oryzae strains.}

raxSTAB homologues from X. oryzae pv. oryzae PXO86 and DY89031 were cloned from a cosmid (Hopkins et al. 1992) and a shotgun library (TOPO Shotgun Subcloning Kit, Invitrogen, Carlsbad, CA, U.S.A.), respectively. $\operatorname{raxST}$ and raxA homologues from CK89021 and C21203 were PCRamplified and sequenced.

\section{Complementation of an $E$. coli tolC mutant with raxC.}

E. coli ZK4 (wild-type strain carrying a genomic copy of tolC) and ZK796 ( $\Delta$ tolC) were used to assay for colicin V secretion (Hwang et al. 1997). Plasmids pHK22 (a pACYC184 derivative containing the $E$. coli MFP $c v a A$ and the ABC transporter $c v a B$ as well as $c v I$ and $c v a C$ genes required for secretion, synthesis, and immunity to colicin $\mathrm{V}$, respectively) and pBSKraxC (pBluescript containing $\operatorname{rax} C$ ) were transformed 
into ZK4 or ZK796 by electroporation. Colicin V activity was assayed by stabbing the $E$. coli strains into Luria-Bertani agar plates containing a $0.7 \%$ agarose overlay mixed with $E$. coli BL21 cells, which are sensitive to colicin V.

\section{ACKNOWLEDGMENTS}

We dedicate this work to the memory of N. T. Keen, our friend and respected colleague. We thank R. Sebastian, P. K. Sharma, C. Azevedo, R. Mcnulty, and N. Mbanugo for technical help, J. E. Leach for providing the PXO86 cosmid library and a summer training internship for F. Goes da Silva, and N. Grimsley and C. Boucher for hosting P. C. Ronald on a sabbatical fellowship. This work was supported by grants from the National Institutes of Health (GM55962), National Science Foundation (9808913), a Guggenheim Fellowship to P. C. Ronald, a Lady Davis fellowship to S. Burdman, and Rockefeller Foundation postdoctoral fellowships to Y. Shen and R. Yadav. C. Dardick was supported in part by a National Institute of General Medical Sciences, Division of Minority Opportunities in Research institutional research and academic career development award to the University of California-Davis.

\section{LITERATURE CITED}

Altschul, S. F., Alejandro, A. S., Zhang, J., Zhang, Z., Miller, W., and Lipman, D. J. 1997. Gapped BLAST and PSI-BLAST: A new generation of protein database search programs. Nucleic Acids Res. 25:3389-3402.

Barton, G. M., and Medzhitov, R. 2003. Toll-like receptor signaling pathway. Science 300:1524-1525.

Bhowmick, N., Huang, J., Puett, D., Isaacs, N. W., and Lapthorn, A. J. 1996. Determination of residues important in hormone binding to the extracellular domain of the luteinizing hormone/chorionic gonadotropin receptor by site-directed mutagenesis and modeling. Mol. Endocrinol. 10:1147-1452.

Bielinska, M. 1987. Sulfation of the choriogonadotropin alpha subunit in human placental explants. Biochem. Biophys. Res. Commun. 148:1446-1452.

Bowman, K. G., and Bertozzi, C. R. 1999. Carbohydrate sulfotransferases: Mediators of extracellular communication. Chem. Biol. 6:R9-R22.

Burdman S., Shen, Y., Lee, S.-W., Xue, Q., and P. Ronald. 2004. axH/RaxR: A two-component regulatory system in Xanthomonas oryzae pv. oryzae required for AvrXa21 activity. Mol. Plant-Microbe Interact. In press.

Che, F.-S., Nakajima, Y., Tanaka, N., Iwano, M., Yoshida, T., Takayama, S., Kadota, I., and Isogai, A. 2000. Flagellin from an incompatible strain of Pseudomonas avenae induces a resistance response in cultured rice cells. J. Biol. Chem. 275:32347-32356.

da Silva, A. C., Ferro, J. A., Reinach, F. C., Farah, C. S., Furlan, L. R., Quaggio, R. B., Monteiro-Vitorello, C. B., Van Sluys, M. A., Almeida, N. F., Alves, L. M., et al. 2000. Comparison of the genomes of two Xanthomonas pathogens with differing host specificities. Nature 406:459-463.

DeFeyter, R., Kado, C. I., and Gabriel, D. W. 1990. Small, stable shuttle vectors for use in Xanthomonas. Gene 88:65-72.

Destoumieux-Garzón, D., Peduzzi, J., and Rebuffat, S. 2002. Focus on modified microcins: Structural features and mechanisms of action. Biochimie 84:511-519.

Dunny, G. M., and Leonard, B. A. B. 1997. Cell-cell communication in gram-positive bacteria. Annu. Rev. Microbiol. 51:527-664.

Ehrhardt, D. W., Atkinson, E. M., Faull, K. F., Freedberg, D. I., Sutherlin, D. P., Armstrong, R., and Long, S. R. 1995. In vitro sulfotransferase activity of NodH, a nodulation protein of Rhizobium meliloti required for host-specific nodulation. J. Bacteriol. 177:6237-6245.

Fath, M. J., Skvirsky, R. C., and Kolter, R. 1991. Functional complementation between bacterial MDR-like export systems colicin V alpha hemolysin and Erwinia protease. J. Bacteriol. 173:7549-7566.

Fath, M. J., Zhang, L. H., Rush, J., and Kolter, R. 1994. Purification and characterization of Colicin V from Escherichia coli culture supernatants. Biochemistry-US 33:6911-6917.

Flor, H. H. 1971. Current status of the gene-for-gene concept. Ann. Rev. Phytopathol. 9:275-296.

Galan, J. E., and Collmer, A. 1999. Type III secretion machines: Bacterial devices for protein delivery into host cells. Science 284:1322-1328.

Girandin, S. E., Boneca, I. G., Carneiro, L. A. M., Antignac, A., Jehanno, M., Viala, J., Tedin, K., Taha, M.-K., Labigne, A., Zathringer, U., Coyle, A. J., DiStefano, P. S., Bertin, J., Sansonetti, P. J., and Philpott, D. J. 2003. Nod1 detects a unique muropeptide from gram-negative bacterial peptidoglycan. Science 300:1584-1587.
Gomez-Gomez, L., and Boller, T. 2000. FLS2: An LRR-receptor like kinase protein involved in the perception of the bacterial elicitor flagellin in Arabidopsis. Mol. Cell 5:1003-1011.

Gomez-Gomez, L., and Boller, T. 2002. Flagellin perception: A paradigm for innate immunity. Trends Plant Sci. 7:251-256.

Hopkins, C. M., White, F. F., Choi, S. H., Guo, A., and Leach, J. E. 1992. Identification of a family of avirulence genes from Xanthomonas oryzae pv. oryzae. Mol. Plant Microbe Interact. 5:451-459.

Hwang, J., Hong, X., and Tai, P. C. 1997. Interactions of dedicated export membrane proteins of the colicin $\mathrm{V}$ secretion system: cvaA, a member of the membrane fusion protein family, interacts with cvaB and tolC. J. Bacteriol. 179:6264-6270.

Inohara, N., and Nunez, G. 2003. Nods: Intracellular proteins involved in inflammation and apoptosis. Nature Rev. Immunol. 3:371-382.

Janeway, C. A., Jr., and Medzhitov, R. 1997. Innate immune recognition. Annu. Rev. Immunol. 20:197-216.

Kakuta, Y., Pedersen, L. E., Pesersen, L. C., and Negishi, M. 1998. Conserved structural motifs in the sulfotransferases family. Trends Biochem. Sci. 23:129-130.

Kearney, B., and Staskawicz, B. J. 1990. Widespread distribtution and fitness contribution of Xanthomonas campestris avirulence gene AvrBs2. Nature 346:385-386.

Kehoe, J. W., and Bertozzi, C. R. 2000. Tyrosine sulfation: A modulator of extracellular protein-protein interaction. Chem. Biol. 7:R57-R61.

Labes, M., Pühler, A., and Simon, R. 1990. A new family of RSF1010derived expression and lac-fusion broad-host-range vectors for gramnegative bacteria. Gene 89, 37-46.

Lorang, J. M., Shen, H., Kobayashi, D., Cooksey, D., and Keen, N. T. 1994. avrA and avrE in Pseudomonas syringae pv. tomato PT23 play a role in virulence on tomato plants. Mol. Plant-Microbe Interact. 7:208215.

Matsubayashi, Y., Ogawa, M., Morita, A., and Sakagami, Y. 2002. An LRR receptor kinase involved in perception of a peptide plant hormone, phytosulfokine. Science 296:1470-1472.

Medzhitov, R. 2001. Toll-like receptors and innate immunity. Nature Rev. Immunol. 1:135-145.

Michiels, J., Dirix, G., Vanderleyden, J., and Xi, C. 2001. Processing and export of peptide pheromones and bacteriocins in gram-negative bacteria. Trends Microbiol. 9:164-168.

Parker, M. W., Tucker, A. D., Tsernoglou, D., and Pattus, F. 1990. Insights into membrane insertion based on studies of colicins. Trends Biochem. Sci. 15:126-129.

Paulsen, I. T., Park, J. H., Choi, P. S., and Saier, M. H. 1997. A family of gram-negative bacterial outer membrane factors that function in the export of proteins, carbohydrates, drugs and heavy metals from gramnegative bacteria. FEMS (Fed. Eur. Microbiol. Soc.) Microbiol. Lett. 156:1-8.

Roche, P., Debelle, F., Maillet, F., Lerouge, P., Faucher, C., Truchet, C., Denarie, J., and Prome, J. C. 1991. Molecular basis of symbiotic host specificity in Rhizobium meliloti: nodH and nodPQ genes encode the sulfation of lipochito-oligosaccharide signals. Cell 67:1131-1142.

Sanger, F., Nicklen, S., and Coulson, A. R. 1977. DNA sequencing with chain-terminating inhibitors. Proc. Natl. Acad. Sci. U.S.A. 74:54635467.

Scheer, J. M. R., and Ryan, Jr., C. A. 2002. The systemin receptor SR160 from Lycopersicon peruvianum is a member of the LRR receptor kinase family. Proc. Natl. Acad. Sci. U.S.A. 99:9585-9590.

Shen, Y., Sharma, P., Silva, F. G., and Ronald, P. 2002. The Xanthomonas oryzae pv. oryzae $\operatorname{rax} P$ and $\operatorname{rax} Q$ genes encode an ATP sulfurylase and APS kinase that are required for AvrXa21 avirulence activity. Mol. Microbiol. 44:37-48.

Shiu, S.-H., and Bleecker, A. B. 2001. Receptor-like kinases from Arabidopsis form a monophyletic gene family related to animal receptor kinases. Proc. Natl. Acad. Sci. U.S.A. 98:10763-10768.

Simpson, A. J. G., Reinach, F. C., Arruda, P., Abreu, F. A., Acencio, M., Alvarenga, R., Alves, L. M. C., Araya, J. E., Baia, G. S., Baptista, C. S. et al. 2000. The genome sequence of the plant pathogen Xylella fastidiosa. Nature 406:151-157.

Slot, K. A. E. V. T., and Knogge, W. 2002. A dual role for microbial pathogen-derived effector proteins in plant disease and resistance. Crit. Rev. Plant. Sci. 21:229-271.

Song, W. Y., Wang, G. L., Chen, L. L., Kim, H. S., Pi, L. Y., Holsten, T. Gardner, J., Wang, B., Zhai, W. X., Zhu, L. H., Fauquet, C., and Ronald, P. C. 1995. A receptor kinase-like protein encoded by the rice disease resistance gene Xa21. Science 270:1804-1806.

Thanabalu, T., Koronakis, E., Hughes, C., and Koronakis, V. 1998. Substrate-induced assembly of a contiguous channel for protein export from E. coli: Reversible bridging of an inner-membrane translocase to an outer membrane exit pore. EMBO (Eur. Mol. Biol. Organ.) J. 17:6487-6496. 
Thanassi, D. G., and Hultgren, S. J. 2000. Multiple pathways allow protein secretion across the bacterial outer membrane. Curr. Opin. Cell Biol. 12:420-430.

Thompson, J. D., Higgins, D. G., and Gibson, T. J. 1994. CLUSTAL W: Improving the sensitivity of progressive multiple sequence alignment through sequence weighting, positions-specific gap penalties and weight matrix choice. Nucleic Acids Res. 22: 4673-4680.

Van Belkum, M. J., Worobo, R. W., and Stiles, M. E. 1997. Double-glycine-type leader peptides direct secretion of bacteriocins by ABC transporters: Colicin V secretion in Lactococcus lactis. Mol. Microbiol. 23:1293-1301.

Wandersman, C., and Delepelaire, P. 1990. TolC, an Escherichia coli outer membrane protein required for hemolysin secretion. Proc. Natl. Acad. Sci. U.S.A. 87:4776-4780.

Wang, G. L., Ruan, D. L., Song, W. Y., Sideris, S., Chen, L., Pi, L.Y., Zhang, S., Zhang, Z., Fauquet, C., Gaut, B. S., Whalen, M. C., and Ronald, P. C. 1998. Xa21D encodes a receptor-like molecule with a leucine-rich repeat domain that determines race-specific recognition and is subject to adaptive evolution. Plant Cell 10:765-779.
Weinshilboum, R. M., Otterness, D. M., Aksoy, I. A., Wood, T. C., Her, C. and Raftogianis, R. B. 1997. Sulfotransferase molecular biology: cDNAs and genes. FASEB (Fed. Am. Soc. Exp. Biol.) J. 11:3-13.

Werling, D., and Jungi, T. W. 2003. TOLL-like receptors linking innate and adaptive immune response. Vet. Immunol. Immunopathol. 91:1-12.

Wilson, K. 1994. Preparation of genomic DNA from bacteria. Pages 2.4.1 2.4.5 in: Current Protocols in Molecular Biology. F. M. Ausubel, R. Brent, R. E. Kingston, D. D. Moore, J. G. Seidman, J. A. Smith, and K. Struhl, eds. John Wiley, New York.

Zhang, L. H., Fath, M. J., Mahanty, H. K., Tai, P. C., and Kolter, R. 1995. Genetic analysis of the Colicin V secretion pathway. Genetics 141:2532.

\section{AUTHOR RECOMMENDED INTERNET RESOURCE}

Moscow State University Genebee molecular biology server Treetop phylogenetic tree prediction website:

www.genebee.msu.su/services/phtree_reduced.html 